\title{
Multi-Criteria Evaluation of Efficiency in Fish Processing
}

\author{
Karlis DREIMANIS ${ }^{1 *}$, Zane INDZERE ${ }^{2}$, Dagnija BLUMBERGA ${ }^{3}$, Vaida SEREVICIENE ${ }^{4}$ \\ ${ }^{1-3}$ Institute of Energy Systems and Environment, Riga Technical University, Azenes iela 12/1, \\ Riga, LV-1048, Latvia \\ ${ }^{4}$ Research Institute of Environmental Protection, Vilnius Gediminas Technical University, \\ Sauletekio ave. 11, Vilnius, Lithuania
}

\begin{abstract}
Carbon neutrality has become a goal of European Union countries as they held agreement on the European Green Deal; the goal needs to be achieved by 2050 . To achieve this goal production industry plays major role as this sector produces considerable amount of greenhouse gas emissions. This paper analyses processes within fish processing industry as the consumption of fish products has increased; therefore, production rate in this area also has been growing. Even more, the consumption of fish products per capita is forecasted to keep increasing for at least the next further years as fish products are great protein source. Thus, it is important to improve efficiency in the fish processing industry, to reduce the amount of emissions, waste and pollution produced in the industry, to evaluate the use of water and energy as well as the resources used in order to achieve sustainable production and carbon neutrality. Data envelopment multicriteria analysis method was used in this research to evaluate energy efficiency in the fish processing industry within sterilization process. The results have shown that the full water immersion autoclave and the water and steam autoclaves are the most efficient from four technologies analysed.
\end{abstract}

Keywords - Data envelopment analysis; fish; manufacturing; production; sterilization; technological process

\section{INTRODUCTION}

Fish product industry is an important food production industry in Latvia. Statistics show that because of various reasons such as technological development, an increase in demand of fish products, and growth of population, the number of fishes caught in a year has increased even multiple times [1].

The efficiency of fish production companies is characterized by the amount of resources used, as well as by energy efficiency, technological improvements [2], the possibility to implement principles of the circular economy (e.g., evaluating life cycle of the product [3]), including criteria that covers sustainable production (environmental, engineering, economic, and social aspects). Energy efficiency directly affects various important processes in the company, for example, production costs, labour costs, and resource and delivery costs.

European Union (EU) member countries have agreed on the European Green Deal and have set a goal to achieve carbon neutrality by 2050 [4]. Different production industries play an important role in achieving this goal. In order for EU member countries to make the most

* Corresponding author.

E-mail address: karlis.d@hotmail.com 
suitable and energy efficient decisions to improve and develop fish processing industry, an overall evaluation can be used where the analysis of factors affecting processing is done, therefore finding improvement opportunities in the industry.

The manufacturing processes and processing indicators of fish industry varies as they depend on the final product. It is essential to considered various factors when choosing the appropriate equipment for the production, for example, fuel consumption, water consumption, amount of GHG emissions and other emissions, amount of waste, sewage, etc. For the manufacturing process to be the most efficient, the equipment which most cost-effective and environmentally friendly must be chosen [6].

One of the resource consuming technological processes within fish processing is sterilization of cans which consumes a rather large amount of energy. Thermal processing within food industry, also including sterilization process, has been defined as a process where the heat is applied to a food product in a container in order to guarantee food safety and to extend shelf-life. Sterilization is defined as a process, which provides near complete inactivation of microorganisms (including spores); however, it could also lead to serious losses in the quality of the products [7].

Sterilization process is known as a very effective food preservation method. In addition, this process is largely used in various food manufacturing areas [7], mostly for fish and meat products, fruits, milk within the food sector; however, it can also be used for such product as ears of corn, coconut water etc. [8]. Coconut water, which is a popular sport drink is sterilized in order to prolong its shelf life without losing quality of the product - the presence of nutritional qualities such as sodium, potassium, total soluble sugar and polyphenol. Sterilization of coconut water increases shelf life from 24 hours to 18 weeks [9].

The most important sterilization factors are time and heating temperature. These factors need to be at their optimal value in order to minimize the losses in the quality of product, such as taste, texture, colour, etc. [10]. Sterilization process is done by applying heat to food products, the temperature is normally between $121{ }^{\circ} \mathrm{C}$ and $134{ }^{\circ} \mathrm{C}$ [11], and time is around 5 to 20 minutes [12]. Both indicators are important as they allow to remove spoilage bacteria spores in order to reach the tolerance level. To perform this step, a thermal process can be done by using specific equipment required for the product.

The sterilization equipment requires the water supply in order to produce the steam. Pressurized steam is used for generation of high temperature. Sterilization equipment, also known as autoclave, is designed and built in a way that the supplied water is boiled in a closed chamber. During this process the pressure rises, which also causes an increase in temperature and ensures that the condition crucial for sterilization (temperature above $100{ }^{\circ} \mathrm{C}$ ) is achieved.

The main components of the autoclave are [11]:

- Heating elements;

- Temperature controller;

- Temperature sensor;

- Chamber;

- Door gasket;

- Solenoid valve;

- Water level sensor.

The two key factors for sterilization are steam and pressure, which ensure that enough heat is created and delivered into microorganisms to eliminate them. According to the autoclave manufacturers, in order for the autoclave to be effective against bacteria, viruses, and forming from spore, it must fulfil the following conditions [11], [13]: 
- Loading of the product must be in a way that it is subject to direct impact of steam;

- The vacuum must be created in order to eliminate all the air initially present in the autoclave by it with a steam;

- A reliable control system must be in operation for the steam evacuation and cooling, otherwise the load can perish;

- The thermal death time needs to be reached - the time which is needed at a reached and maintained temperature for the microbes to be eliminated;

- The thermal death point or temperature at which all microbes in eliminated needs to be achieved.

Thermal sterilization has many advantages, for example, to significantly increase the shelf-life of the processed food. Thermal sterilization restrictions are the losses of the food's nutritional value, as well as the possible changes in the final product, for example, colour, flavour, and texture [9].

However, sterilization techniques are developing and becoming more advanced, including such sterilization methods as: in-package microwave processing, continuous flow microwave heating, radio frequency heating, ohmic heating, infrared heating, as well as other techniques and combinations of traditional and advanced processing methods of heating and cooling [14].

The main aim of this study is to perform an evaluation where technological process sterilization is being analysed by using the multi-criteria analysis (MCA) method data envelopment analysis (DEA) in order to find the most efficient sterilization methods. As far as authors' knowledge is concerned, there are no scientific paper published where various sterilization methods are being compared in the context of canned food in the specific field in order to choose the best technique. This is explained by the specific indicators of sterilization, depending on the food properties, the size of the processing company, quality requirements, etc. However, some examples are available where sterilization methods are compared in different field, for example, sterilization of baby food described by Sarkka-Tirkkonen et al. [15]. The paper discusses and compares various sterilization techniques putting the emphases on the newest methods in the market, for example, ohmic heating, high pressure, high frequency/radio frequency, pulse electric fields etc.

\section{Methodology}

Data envelopment analysis (DEA) is a multi-criteria decision-making (MCDA) method. DEA is an evaluation tool for measuring the efficiency of units. The measurement is done in terms of efficiency defined by the researcher depending on the purpose of the research by Chandrasekar et al. [16]. DEA is a linear programming method which is commonly used where decision making units (DMU) need to be measured. This method allows to set boundaries for the various parameters that are being analysed by Yilmaz and Yurdusev [17]. The model includes a DMU matrix, defining limits, inputs and outputs, and values. The aim of the DEA model is to determine efficiency from two sides - input-oriented or output-oriented models. The input-oriented model refers to maintaining constant production capacity by using minimum inputs; however, the output-oriented model refers to the capacity of DMU in order to reach the maximum of the production volume [17].

According to Chandrasekar, 2017, the data envelopment method (DEA) is a robust quantitative methodology [16]. It allows evaluation of the effectiveness of the chosen methods, approaches, options and items. DEA also allows assessing the necessary improvements for the options to become effective (efficiency frontier). The method of MCA 
allows to compare various scenarios in order to find the most effective solution by the criteria which is defined by the user.

A very important step when applying the DEA model is that the decision maker chooses a set of peer units, DMUs (decision-making units). These DMUs are the criteria or units under evaluation which the evaluator considers important. The DMUs most of the time depend on the sector or area about which the DEA is produced. DEA is developed as a method for evaluation of the performance and benchmarking against best-practice [16].

DEA allows the DMUs to develop an efficiency frontier level. Decision making units are used to develop the frontier also known as efficiency frontier line. The frontier is the best practice option, depending on the chosen and analysed data. The efficiency frontier is the best and most effective solution from the compared option input data [16].

The visual graph of the alternative frontier is used to help the decision makers to easily understand which of the alternatives from DMU are the most efficient, as well as to determine which alternatives needs to be improved to become efficient.

The efficiency frontier line is created using graphical representation and drawn by connecting the efficient points obtained from the DMU. The frontier line displays the performance of the units on the graph in comparison to others [16]. The efficiency of the compared units can be estimated and evaluated from the graph. The points which do not sit on the efficiency line indicate the deviation and show the need for improvements, also known as technical inefficiency.

The line is considered as the benchmark for the efficient results. The points which indicate the unit efficiency in the graph consist of two values which are "allocated efficiency" and "technical efficiency". Allocated efficiency presents the ability of the unit to use the inputs in optimal proportions depending on their characteristics. The technical efficiency presents the unit's ability to gain the maximum outputs from the given set of inputs [16].

The efficiency frontier line is created by connecting the calculated data points of the two values by a straight line. It is important to note that the line must be straight and only linking the closest points to 0 value when looking for the effective or lowest value.

Fig. 1 shows a DMU output-oriented model where the frontier line is developed. The DMU points are plotted on the $\mathrm{x}$ and $\mathrm{y}$ axes, the values of which are showed in Eq. (1), thus determining efficiency frontier. It allows to evaluate which DMU is efficient and which is not. In Fig. 1, alternative A is inefficient, and in order to become an efficient choice, the value from alternative $\mathrm{A}$ to $\mathrm{A}^{\prime}$ needs to be reached.

In this research, DEA method is used to find the most efficient option for technological sterilization process of canned fish product. To conduct DMU matrix for further calculations to find the most efficient sterilization method, specific processing parameters needs to be determined. The DMU matrix is described for a sterilization method with the following parameters: temperature of $120^{\circ} \mathrm{C}$, time for 10 minutes. Four sterilization equipment will be tested in terms of energy used, work capacity - time (output) to fulfil the scenario and criteria. Input is defined as power, manpower is needed to operate, and amount of product sterilized for the determined time. Each input has been assigned a value (weight), therefore it shows which criteria has the most significance compared to other inputs. 


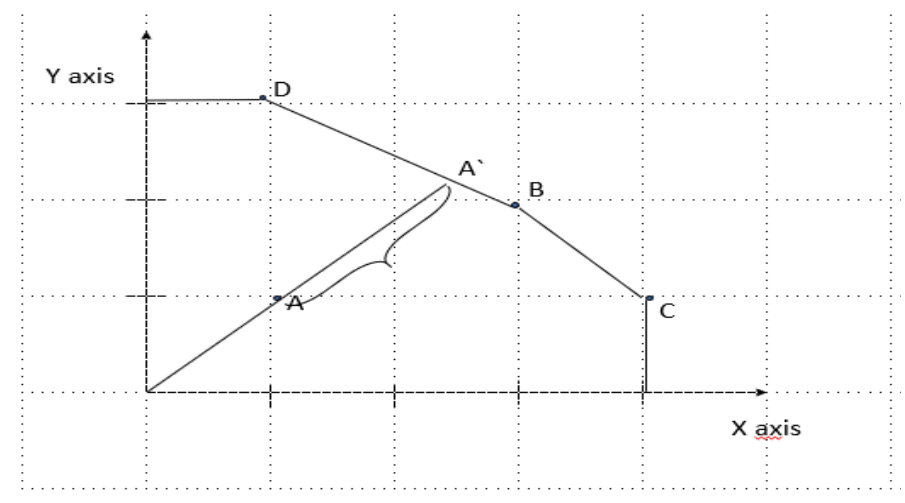

Fig. 1. DEA efficiency frontier (for "the biggest" desired values) [18].

DEA models allow unrestricted weight flexibility when the efficiency scores of DMUs needs to be determined [17]. The first to be performed is compiling a decision-making matrix, including alternatives (various technological processes) and indicators (parameters that are important within the processes).

The efficiency of alternatives is conducted by using Eq. (1). This type of analysis helps to compare the chosen alternatives, as well as to evaluate each alternative's own performance and efficiency.

$$
\text { The efficiency }=\frac{\text { weighted sum of outputs }}{\text { weighted sum of inputs }} .
$$

It is acknowledged that the number of DMU is defined by inputs and outputs. The relative efficiency for DMU can also be solved by using the CCR model [19].

Using the CCR model, the best solution for DMU inputs and outputs is found. The result shows where other alternatives are located one the efficiency graph. It is also possible to determine the least efficient alternative, and their distance from the line. The developed model and results could help fish processing companies to find the most suitable and efficient solution for their technological needs.

\section{Results}

As alternatives, four different sterilization methods have been chosen namely water immersion, water spray, steam, and steam and air. Four indicators have been detected that have shown significant importance on sterilization methods: water consumption, electricity consumption, $\mathrm{CO}_{2}$ emissions, and cost. For analysing autoclave efficiency using the DEA Efficiency frontier method, a specific scenario is created, and assumptions are made.

Firstly, the scenario defines the sterilization method for a certain amount of fish that is needed for a required sterilization. It is said that for the sterilization to be efficient and ensure the requirements for bacteria elimination, the process must be carried out at 120 degrees Celsius at a pressure of $0.3 \mathrm{~Pa}$. The length (time) of the sterilization process varies depending on the product specifics (food type, size, packaging). Some products require the sterilization for up to an hour, but in this DEA modelling, the process is assumed to be 10 minutes long. 
One full cycle of sterilization is examined, during which 1000 cans are inserted into two baskets (trays) filling the autoclave (autoclave length is 2.4 meters). It is assumed that the autoclaves are full and operate for 10 minutes.

The operation costs for the sterilization process (consumed water and energy) are accordingly calculated for the scenario mentioned above. The GHG emissions (in particular $-\mathrm{CO}_{2}$ ) are also calculated using the required energy data.

Table 1 shows frontier data also referred to as a DMU matrix was created to summarize the data used for calculating the efficiency frontier.

TABLE 1. DMU OF STERILIZATION METHODS

\begin{tabular}{lllll}
\hline Method & $\begin{array}{l}\text { Water } \\
\text { consumption, } \\
\mathbf{m}^{3} / \mathbf{1 0 0 0} \text { cans }\end{array}$ & $\begin{array}{l}\text { Electricity } \\
\text { consumption, } \\
\mathbf{k W h} / \mathbf{1 0 0 0} \text { cans }\end{array}$ & $\begin{array}{l}\mathbf{C O}_{2} \text { emissions, } \\
\mathbf{t C O}_{2} / \mathbf{1 0 0 0 c a n s}\end{array}$ & Costs, EUR \\
\hline Water spray retort & 0.095 & 6.5 & 363 & 0.30 \\
Water immersion retort & 0.93 & 9 & 495 & 0.52 \\
Steam and air retort & 0.03 & 8 & 363 & 0.20 \\
Steam retort & 0.05 & 6.5 & 363 & 0.30 \\
\hline
\end{tabular}

The main indicators:

- Input indicators: water consumption $\left(\mathrm{m}^{3}\right)$ and electricity consumptions $(\mathrm{kWh})$;

- Output indicator: costs (euro);

- Additional decision-making factor: $\mathrm{CO}_{2}$ emissions (tons).

The main challenge of the calculation has been data collection, and because it was impossible to obtain the data from fish product (canned fish) manufacturers, the data was obtained from the autoclave manufacturers in Europe and Asia. The following autoclave parameters were obtained from the manufacturers published data on the manufacturers and distributors home pages.

In this case the autoclave chamber length of 2.4 meters is taken as the main factor (criteria) because it shows that the same amount of canned fish products can be installed into the chamber. Considering the data, further calculations show results of the efficiency frontier.

The $\mathrm{CO}_{2}$ emissions were calculated using $\mathrm{CO}_{2}$ emission factors and standards approved by the Ministry of Environmental Protection and Regional Development of the Republic of Latvia [20].

The costs (EUR) associated with water consumption and sewage were calculated using Riga's municipality subsidiary company Ltd "Rīgas ūdens" approved pricing for water and sewage for 2020 [21]. Electricity tariffs are obtained from Latvia's electricity supplier PLC "Sadales tīkls".

Figure 2 shows graphical representation of technologies to be considered efficient and non-efficient. 


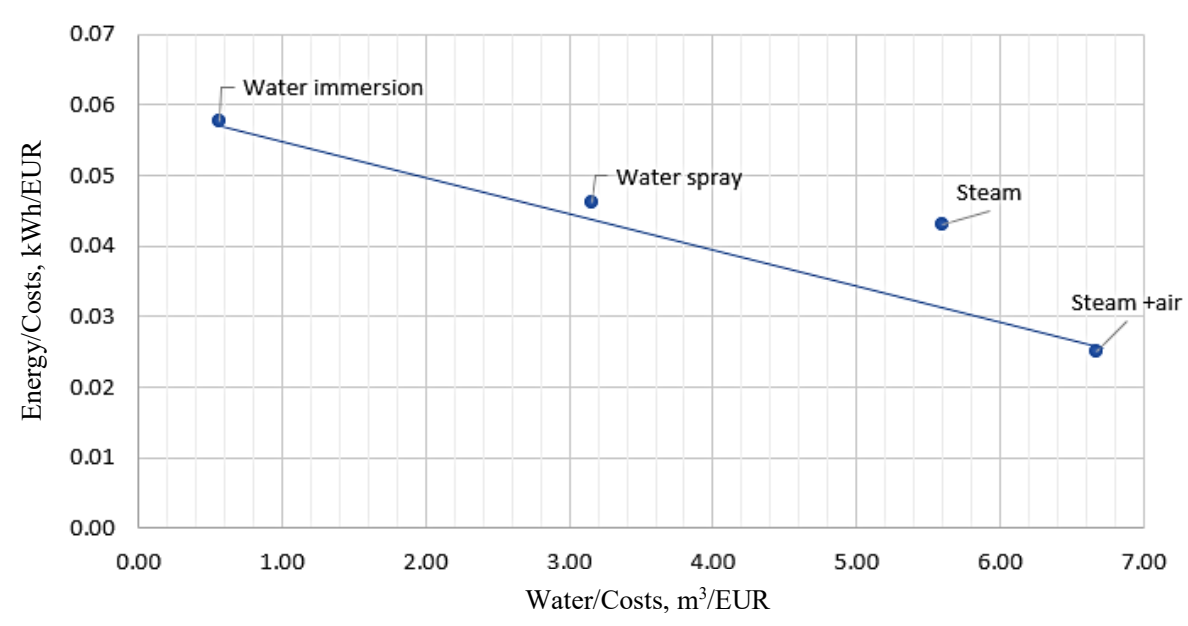

Fig. 2. Efficiency frontier for various sterilization methods.

The chosen parameters on $\mathrm{x}$ axis is water vs costs, and on y axis - energy vs costs.

The aim of the research is to find the efficiency of the autoclaves, by evaluating their performance and minimizing the operational costs which are formed during the production process (water and energy consumption). Additionally, $\mathrm{CO}_{2}$ emissions are evaluated, as indicative results, when choosing the most efficient autoclave. It is important to take $\mathrm{CO}_{2}$ value into consideration, due to the environmental goals in terms of carbon neutrality.

\section{Discussion ANd CONCLuSiONS}

Fish product processing is a large part of manufacturing, using high amounts of resources, for example, water and energy. Therefore, it is strongly advised to improve efficiency in manufacturing, thus allowing to decrease the amount of waste, as the resources used in production would be used in a more efficient and sustainable way.

Within this study, a specific process in food manufacturing was used - sterilization. The aim was to compare various methods of sterilization in order to find the most efficient/inefficient methods. Indicators such as water, energy, costs, and $\mathrm{CO}_{2}$ emissions were considered during the assessment. Data envelopment method was chosen to be used in this research, more specifically - efficiency frontier. Results showed that the most efficient sterilization methods for canned food are water immersion, and steam and air method.

Having evaluated different sterilization techniques, at first glance the conclusion is that canned fish products require specific autoclaves, which can fulfil the necessary requirements for such parameters as temperature, pressure, time. Not all autoclaves are suitable for canned product sterilization. Without having compared autoclave suitability for different purposes, it is clear that one of the most important stages of the canned fish production must meet the technical requirements and also be as efficient as possible (considering the consumption of energy, water and created emissions) to reduce the costs of technological process.

The DEA was successfully applied for the efficiency evaluation of the four same size autoclaves for sterilization. The results were presented in an efficiency frontier graph. Results showed that the full water immersion autoclave and the water and steam autoclaves were the 
most efficient of the four technologies. The other two autoclaves that did not reach the highest efficiency - water spray autoclave and steam autoclave - showed relatively high efficiency values of $85 \%$ and $87 \%$, respectively.

Upcoming policy restrictions and legislation changes due to climate change adaptation and remediation policy, will put additional financial burden on businesses including fish production businesses. Due to the plan of emission reduction and energy efficiency regulation, the fish production processes and technologies used will have to become more efficient and replace the inefficient technologies. New and modern technologies may lead to a case where labour is replaced by technologies as one-time investment in modern and up to date equipment may replace manpower. This future scenario becomes more likely because the manpower cost is around $15 \%$ of total costs.

Obtained results could help manufacturers to make environmentally-friendly decisions when choosing a sterilization method for the company's needs. The change of the equipment used will allow not only to reduce costs but also to reach the environmental goals, set in documents such as the European Green Deal.

\section{ACKNOWLEDGEMENT}

This research is funded by European Maritime and Fisheries Fund, project "Improving production efficiency in the fish processing companies".

\section{REFERENCES}

[1] The Central bureau of statistics. The stats about fish caught. Available: https://www.csb.gov.lv/lv/statistika/statistikastemas/lauksaimnieciba/zivsaimnieciba/meklet-tema/443-nozvejotas-zivis-statistikai100 [05.02.2020]

[2] Kuzmin S., Kadnikova O., Altynbayeva G., Turbit A., Khabdullina Z. Development of a New EnvironmentallyFriendly Technology for Transportation of Mined Rock in the Opencast Mining. Environmental and Climate Technologies 2020:24(1):341-356. https://doi.org/10.2478/rtuect-2020-0019

[3] Lucchetti M. G., Paolotti L., Rocchi L., Boggia A. The Role of Environmental Evaluation within Circular Economy: An Application of Life Cycle Assessment (LCA) Method in the Detergents Sector. Environmental and Climate Technologies 2019:23(2):238-257. https://doi.org/10.2478/rtuect-2019-0066

[4] European Commission. The European Green Deal. Brussels, 2019.

[5] Terehovics E., Veidenbergs I., Blumberga D. Parameters that Affect Electricity Consumption in Fish Freezing. Case Study. Environmental and Climate Technologies 2019:23(3):15-25. https://doi.org/10.2478/rtuect-2019-0076

[6] Featherstone S. A Complete Course in Canning and Related Processes (14th ed.). Vol. 1. Fundamental Information on Canning. Woodhead Publishing Series in Food Science, Technology and Nutrition, 2015.

[7] Li X., Farid M. A review on recent development in non-conventional food sterilization technologies. Journal of Food Engineering 2016:182:33-45. https://doi.org/10.1016/j.jfoodeng.2016.02.026

[8] Park H. W., Yoon W. B. Computational fluid dynamics (CFD) modelling and application for sterilization of foods: A review. Processes 2018:6(6):62. https://doi.org/10.3390/pr6060062

[9] Karmakar S., De S. Cold sterilization and process modeling of tender coconut water by hollow fibers. Journal of Food Engineering 2017:200:70-80. https://doi.org/10.1016/j.jfoodeng.2016.12.021

[10] Park H. W., Yoo J. S., Jung H., Yoon W. B. Developing a sterilization processing and a grading system to produce a uniform quality of sterilized whole corn (Zea mays L. var. ceratina). Journal of Food Engineering 2019:249:55-65. https://doi.org/10.1016/j.jfoodeng.2019.01.005

[11] DTS, 2020. Water immersion autoclave. Available: http://sterileequipment.com/2-1-water-immersion-rotaryretorts/182765/ [Accessed: 15.02.2020.]

[12] Ward D. R. HACCP in the fisheries industry. (Eds.) Bremner A. In Safety and Quality Issues in Fish Processing, Woodhead Publishing Series in Food Science, Technology and Nutrition, 2002, 5-17. https://doi.org/10.1533/9781855736788.1.5

[13] Schneider Electric, 2020. The Sterilization Process (Autoclaves). Available: https://www.eurotherm.com/life-sciencescpg-processes-applications-us/the-sterilizationprocess-autoclaves/ [Accessed: 15.02.2020.]

[14] Richardson P. Thermal technologies in food processing. In Woodhead Publishing Series in Food Science, Technology and Nutrition, Woodhead Publishing, 2001. https://doi.org/10.1533/9781855736610 
[15] Särkkä-Tirkkonen M., Väisänen H. M., Beck A., Kretzschmar U., Seidel K. Overview on different sterilization techniques for baby food. University of Helsinki, 2010.

[16] Cano J. A., Campo E. A., Baena J. J. Application of DEA in international market selection for the export of goods. Dyna 2017:84(200):376-382. http://dx.doi.org/10.15446/dyna.v84n200.63612

[17] Yilmaz B., Yurdusev M. A. Use of Data Envelopment Analysis as a Multi Criteria Decision Tool - A Case of Irrigation Management. Mathematical and Computational Applications 2011:16(3):669-679. https://doi.org/10.3390/mca16030669

[18] Dreimanis K., et al. Multicriteria Evaluaton of Efficiency in Fish Processing. 11 $1^{\text {th }}$ International Conference "Environmental Engineering", Vilnius Gediminas Technical University, Lithuania, 21-22 May 2020. https://doi.org/10.3846/enviro.2020.729

[19] Charnes A., Cooper W. W., Rhodes E. Measuring the efficiency of the decision making units. European Journal of Operational Research 1978:2(6):429-444. https://doi.org/10.1016/0377-2217(78)90138-8

[20] Ministry of Environmental Protection and Regional Development of Latvia, 2018. Siltumnīcefekta gāzu emisiju aprēkina metodika (Calculation methods of greenhouse gas emissions). Available: http://www.varam.gov.lv/lat/darbibas_veidi/Klimata_parmainas/?doc=26279 [Accessed: 24.02.2020]

[21] Rīgas ūdens, 2020. Pakalpojumu veidi un tarifi (Types of services and tariffs). Available: https://www.rigasudens.lv/lv/pakalpojumu-veidi-un-tarifi [Accessed: 24.02.2020] 